\title{
1. Introduction to Philanthropy in Education: Diverse Perspectives and Global Trends
}

\section{Arushi Terway}

In recent years, the changing landscape of philanthropic actors engaging in the development sector and the call for their active involvement in achieving the Sustainable Development Goals have prompted renewed discussions on the role of philanthropy. The topic has gained prominence in the education community at large, but also within international cooperation and development agencies. Philanthropy is being called upon to solve some of the world's most complex social development challenges (see Cohen, 2014; Dean, 2013). This has included initiatives by prominent philanthropists, such as the Giving Pledge that was launched by Warren Buffet and Bill Gates in 2010, to secure commitments from billionaires to give at least half of their wealth to charity. By 2019, 188 billionaires in 22 countries (The Giving Pledge, n.d.) had signed the pledge which could amount to USD 600 billion by the year 2020 (Kotecki, 2018). Given the substantial gap in government and donor funds for education reform in developing countries, many actors in the education community have made the case for finding a philanthropist champion, like Bill Gates, to catalyse discussions and mobilise substantial investments for global education (Brown, 2012; The Global Partnership for Education, 2017; Haslebacher \& van Fleet, 2011). Yet, the role of philanthropies in education reform, especially in developing countries, is severely understudied.

The growth of philanthropic engagement in international development over the past two to three decades has not only demonstrated an increase in the level of philanthropic funding but also a diversity in the location, types of institutions, ideas and approaches to giving (Johnson, 2018; Phillips \& Jung, 2016; Srivastava \& Oh, 2010). This has generated critical debates on the role and approaches of philanthropic engagement in global education between those who support greater involvement of philanthropic organisations in meeting the funding and innovation challenges in the education sector and those who caution us to examine how 
philanthropies, as private actors, change the landscape of education as a global public good. These debates, especially from a range of perspectives, have not been well-published.

This volume seeks to contribute to this emerging debate, taking a unique perspective by bringing together authors from a range of backgrounds: international and national level researchers, staff of philanthropic organisations and staff from coordinating bodies. The chapters in this volume explore some of the most pressing issues facing those working in and engaging in philanthropy and education today.

In this Introduction, I present the trends that can be examined through existing data on the explosion of philanthropy globally and as it impacts education financing. I also explore the complexity in defining what constitutes philanthropy and philanthropic activity and the challenges this presents for conducting comparative research. The rest of the chapters in this book present multiple perspectives on the issues raised in the Introduction. The first set of chapters explores cross-cutting issues related to typologies of philanthropy, global networks and the increasing use of social finance. The second set of chapters looks at regional patterns and trends in philanthropic activity in the Middle East, Africa and global fundraising networks linked to North American universities. And finally, the remaining chapters focus on specific organisations in the following countries: Peru, Brazil, Argentina and Nigeria.

\section{RISING GLOBAL WEALTH AND INCREASE IN PHILANTHROPIC GIVING}

Philanthropy is increasingly gaining attention as a vital additional source of funding, supplementing official development assistance (ODA) for international development (Adelman, 2009; Kharas, 2007; Marten \& Witte, 2008). Decline in ODA for education and the large funding gaps to reach the ambitious aims of the Sustainable Development Goal 4 on education have prompted further discussions on the role of the private sector and philanthropy in education (The International Commission on Financing Global Education Opportunity, 2016; Patrinos \& Sosale, 2007; Steer \& Smith, 2015). The calls for increased philanthropic funds in education are spurred by the consensus that over the last several decades, philanthropic giving to development has increased substantially and has been a game changer at least in the health sector, especially with the engagement of the Bill and Melinda Gates Foundation (Brown, 2012; Haslebacher \& van Fleet, 2011; Phillips \& Jung, 2016; Schäferhoff \& Burnett, 2016). 
In the early twentieth century, with increasing wealth in industrialised nations, Western philanthropists, primarily from the United States, established foundations ostensibly for the improvement of mankind. There was a proliferation of foundations in the United States with 27 foundations in 1915 growing to over 200 by 1930 (Zunz, 2011). Carnegie, Rockefeller, Edward Harkness and Russell Sage Foundations, to name a few, were amongst these early twentieth-century foundations. Overall, these foundations used a 'wholesale' approach rather than a 'retail' approach by tackling the issue of eradicating diseases or improving agricultural yield rather than dealing with individual poverty. Their donations went to universities and research institutes rather than directly to the poor (Cunningham, 2016). These philanthropists were interested in applying rational business methods and principles to charitable giving (McGoey, 2014).

In recent years, the size of philanthropic actors and spending has reached an unprecedented scale. In the United States alone, 75,000 private foundations have been established since the late 1990s, and each year more than 5,000 more philanthropic foundations are started (McGoey, 2014). The most recent report on global philanthropy shows that nearly threequarters of 260,000 foundations in 39 countries were established only in the last 25 years (Johnson, 2018).

The proliferation of foundations has been linked to the substantial lowering of corporate tax rates since the 1980s in the United States (Hungerford, 2013), Silicon Valley or the dot.com boom and as a result an increase in the number of High-Net-Worth Individuals (HNWI). ${ }^{1}$ The number of HNWI globally has increased from 10.9 million in 2010 to 18.1 million in 2017, estimated to be worth more than USD 70 trillion in assets (Capgemini, 2018). The Asia-Pacific region experienced the highest increase (12.1 per cent) in the population of HNWI (Capgemini, 2018); in India alone, HNWI's wealth grew at six per cent per year, from USD 477 billion in 2009 to USD 612 billion in 2013 (Sheth, Ayilavarapu \& Bhagwati, 2015).

Foundations started by these HNWI, corporations and other private actors hold assets greater than USD 1.5 trillion with annual expenditures exceeding USD 150 billion per year (Johnson, 2018). The financial flows from these actors are starting to account for a significant portion of global development funding. The Organisation for Economic Co-operation and Development (OECD) estimated that financial flow from 143 major foundations, working in developing countries around the globe, was USD 24 billion between the years 2013 and 2015, which was equivalent to five per

1 High-Net-Worth Individuals are defined as those who hold at least USD 1 million in assets excluding primary residence. 
cent of the ODA for the same period. Foundations are therefore emerging as significant players in key social sectors like health and education as they appear to dedicate a higher proportion of their funding to the social sector (73 per cent) when compared to ODA flows (37 per cent) (OECD, 2018).

North America and Europe still remain the primary regions where philanthropic institutions are located; however, the sector is starting to flourish in other regions of the world as well. While the availability of data on philanthropic institutions is reasonably comprehensive in North America and Europe, the latest surveys have been able to identify at least 13,170 philanthropic institutions in Asia, 859 in Latin America, 161 in the Middle East and 47 in Africa, with an estimation that many more institutions are not yet captured in these data sets (Johnson, 2018). There is also indication that in many countries, the number of foundations and other philanthropic institutions is increasing rapidly. For example, the number of Chinese foundations increased from less than 200 in 2012 to 5,454 in 2016 (OECD, 2018). Moreover, philanthropies in countries outside of North America and Europe, like China, India, and Turkey are primarily operating and giving within their own borders, with the exception being foundations located in the Gulf that are also investing in projects in other countries. Cross-border or global flows of philanthropic funds are still concentrated towards stable middle-income countries like India, Nigeria, Mexico, China, Ethiopia, South Africa, Kenya and Brazil (OECD, 2018).

Education has emerged as the most popular cause amongst philanthropic institutions (Johnson, 2018; OECD, 2018), but it does not necessarily receive the highest levels of funding as compared to health. Between 2013 and 2015, USD 2.1 billion went to education from 143 foundations globally, but the amount is dwarfed when compared to the USD 12.6 billion that went to health (OECD, 2018). During the same period, USD 25 billion of ODA was spent on education. Philanthropic giving, however, appears to be invested quite differently than the ODA funds. With the very limited available data, indications are that philanthropic giving is going towards challenges that are underinvested by ODA. Based on OECD Development Finance data, ${ }^{2}$ only 0.5 per cent of the ODA funds were dedicated to early childhood education, as compared to five per cent of the philanthropic funds. Similarly, less than one per cent of ODA funds were dedicated to education research, but three per cent of the philanthropic funds were classified for education research. It also appears that philanthropies are spending considerably lower proportions of their funds (six per cent) in primary education when compared to ODA (22 per cent).

2 Data was extracted from the OECD Development Finance Database (http://www.oecd. org/dac/financing-sustainable-development/development-finance-data/). 
Philanthropies are playing an increasing role in global education, but there is still a dearth of data on philanthropies that are located outside of North America and Europe (Phillips \& Jung, 2016; Srivastava \& Oh, 2010). Compared to ODA, the number of philanthropic funds going to global education, that has been documented, are very small, representing about eight per cent of ODA. However, it is important to acknowledge that large philanthropies have the power to exert significant influence in the sector with millions or billions of dollars at their disposal. They can play a complementary role to government efforts; however, without critical and healthy debate over their motivation, approaches and practice, challenges in ensuring equitable distributions of quality education can be exasperated further.

Research is still lacking on not only the actual number of philanthropic actors or the flow of financing, but more importantly, on philosophy and approaches for philanthropic giving. In general, there is a trend that countries with higher GDP experience higher levels of philanthropic giving, but there are also cultural differences in priorities set by philanthropists (Bekkers, 2016). Phillips and Jung (2016) postulate that the 'shifting geography of philanthropy is likely to generate both new intra-regional and transborder patterns' (p.15) that will be different from existing trends of development where financing moves from the Global North to the Global South. The chapter by Bird and Leon in this volume specifically examines the role of philanthropy in the education sector in Peru, a country experiencing a significant decrease in ODA.

Furthermore, philanthropic institutions are engaging in partnerships with public institutions and each other, where complex power relations shape the partnerships themselves in terms of structures, relationships and outcomes (Faul, 2016). Development initiatives globally, in recent years, have moved towards more collaborative and multi-stakeholder approaches for systemic reform rather than isolated one-off projects. These multi-stakeholder partnerships within the education sector have been the unit of analysis in many recent research studies (Chabbot, 2003; Menashy, 2016; Mundy, 1998; Verger, 2012). Few studies, however, have analysed the engagement of philanthropies in these complex partnership networks as the primary unit of analysis (Ball \& Junemann, 2011; Ball \& Olmedo, 2011). Two case studies in this volume, by Santos (Chapter 9) and also Jaumont and Moja (Chapter 7), delve into the dynamics of partnerships between global and local (regional and country level) actors. Additionally, a first of its kind chapter by Haggerty, Magrath and Kelava (Chapter 3) gives an insider view of the formation and operation of an affinity network of global philanthropies working in education. 


\section{WHAT CONSTITUTES 'PHILANTHROPY'?}

Philanthropy, as in donations from wealthy individuals for the welfare of others in society, has a long history in most societies around the globe. Alms giving has its roots in almost all world religions. It is either the responsibility of the rich to share wealth with the poor or give their wealth to the poor to relieve themselves, the rich, of their sins, and the poor in return offer their prayers to rid the rich of their sins (Cunningham, 2016).

Much of the literature on philanthropy focuses on Western conceptions of philanthropy rooted in Christian traditions (Adam, 2004; Arnove, 1980; Ball \& Junemann, 2011; Soskis \& Katz, 2016). During the Enlightenment era, Protestant belief perceived philanthropic activity as a primary duty of the citizen, and it was an avenue to promote public morality, lift the poor and enlighten them for the betterment of all society (Cunningham, 2016). This marked the distinguishing of 'philanthropy' from 'charity', with the view that "indiscriminate charity" simply perpetuated charity. . [and] helping the poor escape poverty through more comprehensive structural reforms. . instilled a confidence in the ability of philanthropy to achieve this' (Phillips \& Jung, 2016, p. 8).

Modern, or at least the Western concept of philanthropy, separates itself from charitable giving, but detangling the two for research purposes still proves to be challenging. The general distinction commonly made is that 'philanthropy' focuses on solutions and aims to treat the root cause of social problems rather than the symptoms, whereas 'charity' involves individual giving directly to people who require services or assistance, so as to mitigate the symptoms (Gross, 2004; Hammack \& Anheier, 2013). Separating the two for research purposes does not prove as simple. Perhaps the key challenge is that in most countries, 'charity' has a legal status whereas 'philanthropy' does not. Generally, 'the legal concept of charity identifies a set of purposes deemed to be "charitable" under common or statutory law that are $[s i c]$ used to legitimize and award to qualifying nonprofits significant tax benefits' (Phillips \& Jung, 2016, p. 10).

Most individual research projects and publications provide a specific definition relevant for their study and draw boundaries around the institutions and activities that can be classified for the particular analysis. But conducting a comparative global analysis of philanthropic activities continues to be a challenge. The challenge is that a number of organisations identify themselves as philanthropies (Eikenberry \& Nickel, 2009; Srivastava \& Oh, 2010), when these organisations would be classified by their legal structures and by others as charities. There is often confusion about a non-profit organisation that receives funds from elsewhere to operate as opposed to a philanthropic organisation that has its own endowment 
or independent revenue stream. Additionally, philanthropies with independent sources of funding also vary considerably in the source of funding from private wealthy individuals, families, corporations, communities, individual citizens and even government entities (Leat, 2016; Srivastava \& Oh, 2010). The chapter by Ridge, Kippels and Bruce (Chapter 5) in this volume examines the relationship between funding source and activities for the Middle East and North Africa (MENA) region.

Beyond the source of funding, the mode of giving also creates a challenge in defining 'philanthropy' across the globe. The emergence of 'new' philanthropy, which does not necessarily refer to the recent establishment of a philanthropic organisation, has blurred the lines between grant-making for social development versus financial investment in social projects that are profit-seeking. 'New' philanthropies often use a variety of qualifiers like strategic, venture, entrepreneurial, catalytic, high impact, social change, results-driven, and so on, which are all borrowed from the business world. These terms are not necessarily new when compared to the philosophies adopted by early twentieth-century philanthropists. In an interview with McGoey (2014), William Schambra, director of the Washington, DC-based Hudson Institute's Bradley Center for Philanthropy and Civic Renewal, explained, 'The notion that we should organise our philanthropies the way we organise our corporations - that was John D. Rockefeller's original idea' (p.111).

The shift here is more nuanced with the adoption of "philanthrocapitalism' and the introduction of financial gains as a legitimate measure of effective philanthropy. The term 'philanthrocapitalism' was coined by Matthew Bishop and Michael Green (2008), and Bishop (2009) explained it as follows:

Philanthrocapitalism is about combining the head and the heart, by bringing a businesslike approach to solving society's problems. . . Both Clinton and Blair pointed out that government tends to be hopeless at innovation, unlike the private sector, both for-profit and non-profit. If there is to be change we can believe in, government must embrace these changemakers in new partnerships, especially social entrepreneurs. . . money earned by harnessing the profit motive can help achieve change faster, and more sustainably than old-fashioned charity alone. . . [It is] about doing well by doing good. . . Old-fashioned capitalism is dead. Long live philanthrocapitalism. (para. 2-12)

This approach has conflated actors and modes of philanthropy-social enterprise, corporate social responsibility (CSR), venture philanthropy, impact investment, and so on (Edwards, 2009; Srivastava \& Oh, 2010). Many philanthropic actors are now utilising social finance, the use of private capital for social projects, which aims to yield a social return 
along with a financial return. This approach has dissolved the separation between 'grant-making', the mode of giving funds to social projects, and 'investment', the mode of expanding the endowment, within foundations (Phillips \& Jung, 2016). A sample of 699 foundations in 12 countries showed that 16 per cent of the foundations were making equity investments, 11 per cent were providing loans and eight per cent were engaged in impact investment (Johnson, 2018). Mixing profit-seeking goals within the education sector creates legitimate tensions and scepticism by many on the motives of the actors in ensuring equitable access to quality education.

In this volume, Srivastava and Read (Chapter 2) discuss the challenges with defining philanthropy within the education sector and work towards a typology in the emerging hybridity of actors. Ziswiler and Terway (Chapter 4) further explore the social finance approach and its applicability to the education sector. Additionally, case study research in this volume, on corporate philanthropy in Nigeria by Udo-Umoren (Chapter 10) and on Varkey Foundation's entry into Argentina by Matovich and Cardini (Chapter 11), further elaborates on variation in the manifestation of 'new' philanthropy at the national level.

While much attention in literature has gone to the dynamics of institutional philanthropy, much of philanthropic giving is done by individuals. In the United States, 70 per cent of philanthropic giving in 2017 was by individuals (Giving USA, 2018). In fact, individuals are also exploring market-based social finance tools through pensions and other investment funds to channel funds towards social development (Phillips \& Jung, 2016). However, little is known about motivation and modality of giving by individuals around the world. The chapter by Drezner specifically explores global growth in alumni giving to higher education as not purely a U.S. phenomenon.

Information on philanthropic actors in North America and Europe are fairly well documented through sources like the Council on Foundations, the Foundation Center, the European Foundation Centre and the Hudson Institute, which help distinguish or define philanthropies using financial and activity data. However, the availability of data on philanthropic actors in other regions of the world is still lacking. The chapter by Ridge, Kippels and Bruce (Chapter 5) takes on the challenge of collecting data and analysing patterns of education funding from philanthropies in the MENA region.

Many questions still remain unanswered, especially in the education sector: What are the regional and organisational differences in how philanthropies operate? How does the relationship between the public and private sector change as a result of philanthropic activities? How do philanthropies approach the issues of social responsibility, equity and 
sustainable development? What lessons can be learned from other sectors (e.g., health sector) or specific areas within the education sector (e.g., early childhood education and vocational-technical education) when looking back at the long history of collaboration between the public and private sector?

This volume begins to fill this gap by bringing in research and knowledge on philanthropic giving in the Global South. Authors in the volume represent varied affiliations. They are researchers from academic institutions in the Global South, philanthropic foundations, a consulting firm and a social finance investment firm and philanthropic network coordinators. The authors explore the many ways in which philanthropic actors are engaging not only with national education systems in a variety of countries, including Argentina, Brazil, Peru and Nigeria, but also larger trends in the sector such as new approaches to finance, the role of global policy partnerships and expanded possibilities for CSR through corporate foundations. Authors also examine and challenge the commonly held perceptions of actor relationships in philanthropic spaces and the need for greater collaboration and communication between national governments, international organisations, academia and philanthropic organisations.

\section{OVERVIEW OF CHAPTERS}

The first section of the book, comprising three chapters, takes a global view on cross-cutting issues such as terminology, networks and financing modalities.

Srivastava and Read in Chapter 2 explore challenges for the research community due to the lack of common terminology for private actors in education. In conducting a definitional exercise, they find that definitions used in conceptual literature, or by the actors themselves and regulatory structures, do not adequately capture the hybrid nature of private foundations and impact investors. Through an inductive exercise, the authors present a working typology of organisational forms of private foundations, impact investors and other actors that are developing the field.

In Chapter 3, Haggerty, Magrath and Kelava open up the black box of a philanthropic affinity network as a knowledge-sharing and collaboration project between very diverse philanthropic institutions working in global education. The International Education Funders Group (IEFG) includes over 100 large and small foundation members from across the globe that are wide-ranging types of institutions such as family philanthropies, corporate philanthropies, CSR arms of companies, banks with philanthropic funding from HNWIs or donor-advised funds. This chapter explains how 
these philanthropic actors came together to pursue learning within the philanthropic sector to improve effectiveness and efficiency of collective education grant-making by providing knowledge-sharing, coordination and networking opportunities for members.

Next, using the case of the UBS Optimus Foundation, Ziswiler and Terway explore the potential of the philanthropic sector in creating an ecosystem for social finance within the education sector. They argue that social finance has the potential to draw additional private capital to drive positive social change by catalysing innovative solutions to complex problems, striking the right balance between risk and reward while maximising social impact. The authors also consider pitfalls associated with using social finance in education and caution against perceiving social finance as a panacea to education sector funding challenges.

The second section of the volume, with its regional focus, looks at patterns and trends in philanthropic activity in the Middle East and Africa and the global rise of higher education fundraising efforts as not just a North American phenomenon.

In Chapter 5, Ridge, Kippels and Bruce identify and examine 65 philanthropic entities operating in the education sector across 11 countries in the MENA region. They identify three types of philanthropic organisations in the region: state-funded, corporate-funded and private individual/family funded and find that the source of funding in philanthropic organisations plays a significant role in the priorities of organisations. Their research also finds that philanthropic giving tends to go to programmatic work and scholarships and that there is less given to research on education.

Drezner's chapter examines possible explanations for the growth of philanthropic giving towards higher education expanding beyond North America. He identifies three primary reasons for this global growth: (1) a functional need for philanthropic support of higher education, (2) a form of isomorphism where institutions are striving for prestige and (3) a result of borrowing and lending of perceived best practices.

Last in this section, Jaumont and Moja research the longstanding partnerships between U.S. foundations and universities in Africa. They highlight the complex dynamics between the institutions and explain how U.S. foundations have positioned themselves strategically in the ecology of international developers and have succeeded in advocating the importance of higher education for African economic development. They also find that donor-to-recipient collaborations are not set on equal footing and examine the implications of this inequity.

The third section of the volume covers four specific country case studies highlighting philanthropic activities in education in Peru, Brazil, Nigeria and Argentina. 
Bird and León, in Chapter 8, examine the role of philanthropic investment in the education sector in Peru in filling the development financing gap left by lower levels of ODA. Their research is based on data from a survey of 157 philanthropic and social investment organisations across 10 cities in Peru. Their research finds that organisations that demonstrate greater institutional quality, as measured by transparency, governance and operational mechanisms with a focus on improving educational quality, appeared to be best positioned to forge new pathways to generate impact at scale.

Exploring the universe of science fairs in Brazil, Santos examines the influence of Intel Corporation on the development of a diversified science curriculum. His research explores the tensions surrounding the use of corporate funding to promote education reform. This case study highlights how international philanthropic work in science education can contradict the basic principles of a country's education system, as well the need for a discussion about the influence of international programs of CSR in education.

Also tied to corporate responsibility, Udo-Umoren's study on Nigerian CSR initiatives finds that motivations influencing CSR initiatives range from altruism to strategic philanthropy. The research finds that the major form of CSR contributions to education by Nigerian companies is financial resources and that they are largely uncoordinated and fragmented. Udo-Umoren highlights the need for greater research on the topic to better understand how these contributions may be influencing quality and equity in education.

Chapter 11 presents Matovich and Cardini's research focusing on the Varkey Foundation's education influence in Argentina. They find that neoliberal discourses and practices have been reproduced and mobilised through the Varkey Foundation's operations. They also reflect on the possibility of considering this programme as a burgeoning case of new philanthropy penetration in Argentina and its influence on public policy-making.

The volume concludes with reflections from Ridge on persisting and growing challenges related to the North-South divide in the aid sector in general and philanthropic engagement in education more specifically. She draws on learning from the other chapters in the book to highlight the need for collaboration between different actors, the growing influence of the private sector through philanthropy and the critical concerns over accountability and transparency in the sector. 


\section{REFERENCES}

Adam, T. (Ed.). (2004). Philanthropy, patronage and civil society: Experiences from Germany, Great Britain and North America. Bloomington, IN: Indiana University Press.

Adelman, C. (2009). Global philanthropy and remittances: reinventing foreign aid. Brown Journal of World Affairs, 15(2), 22-33.

Arnove, R. F. (Ed.) (1980). Philanthropy and cultural imperialism: The foundations at home and abroad. Boston, MA: G. K. Hall.

Ball, S. J., \& Junemann, C. (2011). Education policy and philanthropy: the changing landscape of English educational governance. International Journal of Public Administration, 34(10), 646-661.

Ball, S. J., \& Olmedo, A. (2011). Global esocial capitalism: using enterprise to solve the problems of the world. Citizenship, Social and Economics Education, 10(2), 83-90.

Bekkers, R. (2016). Regional differences in philanthropy. In T. Jung, S. D. Phillips, \& J. Harrow (Eds.), The Routledge companion to philanthropy (pp.124-138). Abingdon, UK: Routledge.

Bishop, M. (2009). Philanthrocapitalism: Yes we can. Huffington Post. Retrieved June 21, 2019, from http://www.huffingtonpost.com/matthew-bishop/philanthro capitalism-yes_b_163253.html

Bishop, M., \& Green, M. (2008). Philanthrocapitalism: How the rich can save the world. New York, NY: Bloomsbury Press.

Brown, B. (2012). Delivering on the promise, building opportunity: The case for a Global Fund for Education. A review by Gordon Brown. London, UK: The Office of the UN Special Envoy for Global Education. Retrieved February 22, 2019, from http://educationenvoy.org/speeches-and-research/

Capgemini. (2018). World wealth report 2018. Paris, France: Author. Retrieved June 21, 2019, from https://www.capgemini.com/wp-content/uploads/2018/06/Capge mini-World-Wealth-Report.pdf

Chabbott, C. (2003). Constructing education for development: International organizations and Education for All. London, UK: Routledge.

Cohen, R. (2014). How the other half gives: philanthropy from high net worth individuals. Nonprofit Quarterly. Retrieved June 21, 2019, from https://nonprofit quarterly.org/2014/11/18/how-the-other-half-gives-philanthropy-from-high-networth-individuals/

Cunningham, H. (2016). The multi-layered history of Western philanthropy. In T. Jung, S. Phillips, \& J. Harrow (Eds.), The Routledge companion to philanthropy (pp. 42-55). Abingdon, UK: Routledge.

Dean, M. (2013). UK philanthropy needs to up its game. The Guardian. Retrieved June 21, 2019, from https://www.theguardian.com/society/2013/oct/15/uk-philanth ropy-up-game

Edwards, M. (2009). Gates, Google, and the ending of global poverty: philanthrocapitalism and international development. Brown Journal of World Affairs, 14(2), 35-42.

Eikenberry, A. M., \& Nickel, P. M. (2009). A critique of the discourse of marketized philanthropy. American Behavioral Scientist, 52(7), 974-989.

Faul, M. V. (2016). Multi-sectoral partnerships and power. Background Paper prepared for the UNRISD flagship report 2016 Policy Innovations for Transformative Change. Geneva, Switzerland: UNRISD. Retrieved June 21, 2019, from http:// 
www.unrisd.org/80256B3C005BCCF9/(httpAuxPages)/CA910973B03CB947C1 258061006504BB/\$file/Faul\%20BP.pdf

The Giving Pledge. (n.d.). A commitment to philanthropy. Retrieved June 21, 2019, from https://givingpledge.org/Home.aspx

Giving USA. (2018). The annual report on philanthropy for the year 2018. Indianapolis, IN: Giving USA Foundation and Indiana University Lilly Family School of Philanthropy.

The Global Partnership for Education. (2017). Fund education shape the future: Case for investment. Washington, DC: Author. Retrieved June 21, 2019, from https:// www.globalpartnership.org/sites/default/files/2017-05-gpe-case-for-investmentupdated.pdf

Gross, R. A. (2004). Giving in America: From charity to philanthropy. In L. J. Friedman \& M. D. McGarvie (Eds.), Charity, philanthropy and civility in American history (pp. 29-48). Cambridge, UK: Cambridge University Press.

Hammack, D. C., \& Anheier, H. K. (2013). A versatile American institution: The changing ideals and realities of philanthropic foundations. Washington, DC: The Brookings Institution.

Haslebacher, L., \& van Fleet, J. (2011). Where is the Bill Gates of global education? Brookings. Retrieved June 21, 2019, from https://www.brookings.edu/blog/ up-front/2011/08/18/where-is-the-bill-gates-of-global-education/

Hungerford, T. (2013, June 4). Corporate tax rates and economic growth since 1947. Economic Policy Institute Issue Brief, 364. Retrieved June 21, 2019, from https:// www.epi.org/publication/ib364-corporate-tax-rates-and-economic-growth/

The International Commission on Financing Global Education Opportunity. (2016). The learning generation: Investing in education for a changing world. New York, NY: The Education Commission. Retrieved June 21, 2019, from http://report.educationcommission.org/wp-content/uploads/2016/09/Learning Generation_Full_Report.pdf

Johnson, P. (2018). Global philanthropy report: Perspective on the global foundation sector. Cambridge, MA: Harvard Kennedy School, The Hauser Institute for Civil Society at the Center for Public Leadership. Retrieved June 21, 2019, from https:// cpl.hks.harvard.edu/files/cpl/files/global_philanthropy_report_final_april_2018. pdf

Kharas, H. (2007). The new reality of aid. Paper presented at the Brookings Blum Roundtable 2007, August. Washington, DC. Retrieved June 21, 2019, from https:// www.brookings.edu/wp-content/uploads/2012/04/2007kharas.pdf

Kotecki, P. (2018). The billionaire 'Giving Pledge' signed by Bill Gates and Elon Musk could soon be worth up to $\$ 600$ billion. Business Insider. Retrieved June 21, 2019, from https://www.businessinsider.com.au/bill-gates-elon-musk-givingpledge-may-reach-600-billion-2018-7? $r=\mathrm{US} \& I R=\mathrm{T}$

Leat, D. (2016). Private and family foundations. In T. Jung, S. D. Phillips, \& J. Harrow (Eds.), The Routledge companion to philanthropy (pp.293-307). Abingdon, UK: Routledge.

Marten, R., \& Witte, J. M. (2008). Transforming development?: The role of philanthropic foundations in international development cooperation (GPPI Research Paper Series, No. 10). Berlin, Germany: Global Public Policy Institute. Retrieved June 21, 2019, from https://www.gppi.net/media/marten-witte_2008_transformingdevelopment-philanthropic-foundations.pdf

McGoey, L. (2014). The philanthropic state: market-state hybrids in the philanthrocapitalist turn. Third World Quarterly, 35(1), 109-125. 
Menashy, F. (2016). Private authority or ambiguity? The evolving role of corporations and foundations in the Global Partnership for Education. In A. Verger, C. Lubienski, \& G. Steiner-Khamsi (Eds.), World yearbook of education 2016: The global education industry (pp. 63-77). Abingdon, UK: Routledge.

Mundy, K. (1998). Educational multilateralism and world (dis)order. Comparative Education Review, 42(4), 448-478.

Organisation for Economic Co-operation and Development. (2018). Private philanthropy for development. Paris, France: Author. Retrieved June 21, 2019, from https://read.oecd-ilibrary.org/development/private-philanthropy-for-development _9789264085190-en\#page 1

Organisation for Economic Co-operation and Development. (n.d.). Development finance data [Data set]. Retrieved June 21, 2019, from http://www.oecd.org/dac/ financing-sustainable-development/development-finance-data/

Patrinos, H. A., \& Sosale, S. (Eds.). (2007). Mobilizing the private sector for public education: A view from the trenches. Washington, DC: World Bank. Retrieved June 21, 2019, from http://siteresources.worldbank.org/EDUCATION/Resour ces/2782001099079877269/547664-1099079934475/Mobilizing_PrivateSector_Pu blicEdu.pdf

Phillips, S. D., \& Jung, T. (2016). Introduction. A new 'new' philanthropy: from impetus to impact. In T. Jung, S. D. Phillips, \& J. Harrow (Eds.), The Routledge companion to philanthropy (pp. 1-26). Abingdon, UK: Routledge.

Schäferhoff, M., \& Burnett, B. (2016). Rethinking the financing and architecture of global education (Background Paper for The Education Commission). New York, NY: The Education Commission. Retrieved June 21, 2019, from http://report.edu cationcommission.org/wp-content/uploads/2017/03/Rethinking-the-Financingand-Architecture-of-Global-Education.pdf

Sheth, A., Ayilavarapu, D., \& Bhagwati, A. (2015). India philanthropy report 2015. Boston, MA: Bain \& Company. Retrieved June 21, 2019, from https://www.bain. com/insights/india-philanthropy-report-2015/

Soskis, B., \& Katz, S. (2016). Looking back at 50 years of U.S. philanthropy. Menlo Park, CA: The William and Flora Hewlett Foundation.

Srivastava, P., \& Oh, S. A. (2010). Private foundations, philanthropy, and partnership in education and development: mapping the terrain. International Journal of Educational Development, 30(5), 460-471.

Steer, L., \& Smith, K. (2015). Financing education: Opportunities for global action. Washington, DC: Brookings Institution. Retrieved June 21, 2019, from https:// www.brookings.edu/wp-content/uploads/2016/07/FinancingForEducation2015. pdf

Verger, A. (2012). Framing and selling global education policy: The promotion of public-private partnerships for education in low-income contexts. Journal of Education Policy, 27(1), 109-130.

Zunz, O. (2011). Philanthropy in America: A history. Princeton, NJ: Princeton University Press. 